\section{Peptidyl-transfer RNA hydrolase prevents inhibition of protein synthesis initiation}

PEPTIDYL-tRNA HYDROLASE (called hydrolase below) catalyses the hydrolysis of peptides from peptidyl-tRNAs that are not bound to ribosomes ${ }^{1,2}$ but will not hydrolyse amino acyl-tRNA or fMet-tRNA $A_{f}^{\text {Met }}$. It is interesting that hydrolase seems to be ubiquitous in nature; it has been found in all cells where it has been sought, including yeast ${ }^{3}$, bacteria, rat liver and jackbeans ${ }^{4}$. However, the metabolic role of this enzyme has not been established. It is required for normal function, as a mutant strain of Escherichia coli with a temperature-sensitive hydrolase cannot continue protein synthesis at the nonpermissive temperature ${ }^{5}$. Hydrolase itself is not required for initiation, elongation or termination phases of protein synthesis ${ }^{6}$. Menninger ${ }^{7}$ has shown that peptidyl-tRNA, formed on ribosomes, accumulates at nonpermissive temperatures in cells with the temperature-sensitive hydrolase. Hydrolase thus seems to be a scavenger enzyme of peptidyl-tRNAs normally aborted from ribosomes during protein synthesis. Of interest now is why peptidyl-tRNA is frequently prematurely released from ribosomes and why protein synthesis is inhibited in the mutant strain with a defective hydrolase ${ }^{5}$. I report here work on the latter problem and present evidence which indicates that peptidyltRNAs accumulate and compete with $N$-formyl-Met tRNA ${ }_{f}^{\text {Met }}$ during initiation of protein synthesis.

Two possible mechanisms of protein synthesis inhibition at $42^{\circ} \mathrm{C}$ in the temperature-sensitive hydrolase strain are that one or more infrequently occurring tRNAs may become sequestered as peptidyl-tRNA, resulting in inhibition of polypeptide elongation or, on the other hand, that the only known product of the reaction (peptidyl-tRNA) may interfere with initiation of polypeptides. Peptidyl-tRNA is not unlike $N$-formyl-MettRNA ${ }_{t}^{\text {Met }}$. Thus, these two similar compounds may compete at initiation for the P-site on the ribosome.

When the hydrolase mutant strain is incubated at temperatures intermediate between permissive growth and nonper-

Table 1 Amino acid polymerisation and growth rates at various temperatures

\begin{tabular}{|c|c|c|c|c|}
\hline Strain & $\begin{array}{c}\text { Growth } \\
\text { temperature }\end{array}$ & $\begin{array}{c}\text { Doubling } \\
\text { time } \\
\text { (min ) }\end{array}$ & $\begin{array}{l}\text { Polymerisation } \\
\text { rate (amino } \\
\left.\text { acids } s^{-1}\right)\end{array}$ & $\begin{array}{c}\text { Initial slope } \\
\text { of induction } \\
\text { curve } \\
\text { (nmol ONPG } \\
\text { hydrolysed } \\
\text { per min per } \\
3 \times 10^{8} \text { cells) }\end{array}$ \\
\hline \multirow[t]{5}{*}{ AA-7852 } & $30.0 \pm 0.05$ & $190 \pm 5$ & $5.6 \pm 0.3$ & 55 \\
\hline & $37.0 \pm 0.05$ & $170 \pm 5$ & $6.8 \pm 0.2$ & 57 \\
\hline & $40.0 \pm 0.05$ & $210 \pm 8$ & $7.5 \pm 0.2$ & 42 \\
\hline & $41.0 \pm 0.05$ & $270 \pm 10$ & $7.3 \pm 0.2$ & 29 \\
\hline & $41.5 \pm 0.05$ & $300 \pm 10$ & $7.3 \pm 10$ & 21 \\
\hline \multirow[t]{2}{*}{ CP-78 } & $30.0 \pm 0.05$ & $150 \pm 5$ & $6.1 \pm 0.3$ & 72 \\
\hline & $40.0 \pm 0.05$ & $110 \pm 5$ & $9.1 \pm 0.2$ & 75 \\
\hline
\end{tabular}

Cells were grown in M-9 medium with $0.4 \%$ glycerol and required amino acids in a gyrorotary shaking water bath at the specified temperature $^{6}$. Strains CP-78 (a K12 strain of E. coli, arg, his, leu, thr, thi) and AA-7852 (a single-step mutant of strain CP-78 that is now temperature-sensitive for peptidyl-tRNA hydrolase (ref. 5) were induced for $\beta$-galactosidase synthesis by addition of $5 \mathrm{mM} \mathrm{3}$, $5^{\prime}$-cyclic AMP and 1 $\mathrm{mM}$ isopropylthiogalactoside after growth at the specified temperature for 2 hours. The cultures were sampled every $5 \mathrm{~s}$ by taking $0.5 \mathrm{ml}$ into test tubes containing $0.50 \mathrm{ml}$ of a solution $\left(1 \mathrm{mg} \mathrm{ml}^{-1}\right)$ of chloramphenicol in distilled water ${ }^{8}$. These samples were assayed for $\beta$-galactosidase activity by cell lysis with toluene and hydrolysis of $o$-nitrophenol- $\beta$-D-galactopyranoside (ONPG) at $25^{\circ} \mathrm{C}$. Polymerisation rate was established by the time required for the first newly synthesised $\beta$-galactosidase molecules to appear ${ }^{8,9}$. There are 1,021 amino acids in $\beta$-galactosidase ${ }^{10}$. A change of $0.004 A_{420}$ units equals $1 \mathrm{nmol}$ of $\mathrm{ONPG}^{11}$ missive growth $\left(40,40.5,41^{\circ} \mathrm{C}\right)$, partial inhibition of growth is observed. This is interpreted as limited inactivation of hydrolase, resulting in a reduced rate of peptidyl-tRNA hydrolysis. If elongation rates are affected at these intermediate temperatures, protein polymerisation time should be increased. If initiation of protein synthesis is inhibited, however, the polymerisation rate will remain unchanged for a specific protein.

The time lag between the induction of the lactose operon and the first appearance of $\beta$-galactosidase activity above basal enzyme level was used to estimate the peptide chain elongation rate $^{8,9}$. It has been shown that this approach is not a reflection of changed mRNA synthesis times ${ }^{8}$. Hence a measure of polymerisation time of $\beta$-galactosidase can differentiate between the two possibilities outlined above.

The data presented in Table 1 indicate that the rate of peptide-chain elongation does not change significantly with increase in growth temperature in the hydrolase temperaturesensitive strain. The chain elongation rate is slightly less in the mutant strain at $40^{\circ} \mathrm{C}$ than in the parent strain $(20 \%)$, but nearly identical at the permissive temperature $\left(30^{\circ} \mathrm{C}\right)$. However, the growth rate of the mutant strain decreases considerably as the growth temperature is increased from 37 to $41.5^{\circ} \mathrm{C}$, reflecting inhibition of protein synthesis by steadily increasing concentrations of peptidyl-tRNA in the cell. Furthermore, the relative rate of polypeptide chain initiation is proportionally decreased (Table 1, column 5). These data are derived from the initial slope of the induction curve; they reflect the relative number of molecules synthesised per unit time. The relative number of chain initiations in strain AA-7852 $\left(p t h^{t s}\right)$ decreases by slightly more than half from 40 to $41.5^{\circ} \mathrm{C}$, and the doubling time decreases proportionally. No significant growth or $\beta$-galactosidase induction is observed at $42^{\circ} \mathrm{C}$, reflecting complete inactivation of the hydrolase.

Other data suggesting that initiation of protein synthesis is inhibited in the hydrolase mutant strain at the nonpermissive temperature come from studies of the polysome distribution after shift to $43^{\circ} \mathrm{C}$. Menninger et al $^{6}$ found that polysomes slowly dissociated at $43^{\circ} \mathrm{C}$, forming $70 \mathrm{~S}$ subunits. Elongation continues temporarily, resulting in dissociation of polysome structures. However, initiation only forms $70 \mathrm{~S}$ units, possibly because of a peptidyl-tRNA in the P-site. This is consistent with the idea that some poison accumulates, very probably peptidyltRNA, but must reach a critical level before inhibition is seen. Protein synthesis is not inhibited in the hydrolase mutant until about $10 \mathrm{~min}$ after transfer to the nonpermissive temperature.

In conclusion these data show that the number of polypeptide chain initiations decreases as hydrolase is partly inactivated. On the other hand, the chain elongation rate is not affected. These findings imply that hydrolase plays an important part in cell metabolism by destroying spontaneously formed peptidyltRNAs which, in turn, inhibit protein synthesis initiation, probably by competing with $N$-formyl-Met-tRNA ${ }_{\mathrm{f}}^{\text {met }}$ in the $\mathrm{P}$-site of the ribosome.

This investigation was supported by the Iowa Agriculture and Home Economics Experiment Station and a grant from the NSF. I thank Mary Mascia for technical assistance.

\section{AL.AN G. ATHERLY}

Department of Genetics,

Iowa State University,

Ames, Iowa 50011

Received 29 June, accepted 8 September 1978

1. Lapidot, Y. \& deGroot, N. Prog. Nucleic Acid Res. molec Biol. 12, 189--228 (1972)

2. Menninger, J. R., Mulholland, M. C. \& Stirewalt, W. C. Biochim. biophys. Acta 217, 496-511 (1970)

3. Jossel, H. \& RayBhandary, U. L. J. molec. Biol. 35, 539-560 (1968).

4. Menninger, J. R., Deery, S., Draper, D. \& Walker, C. Biochim. biophys. Acta 335, 185-195 (1974).

5. Atherly, A. G. \& Menninger, J. R. Nature new Biol. 240, 245-246 (1972)

6. Menninger, J. R., Walker, C., Tan, P. F. \& Atherly, A. G. Molec. gen. Genet. 121, 307-324 (1973).

7. Menninger, J. R. J. biol. Chem. 251, 3392-3398 (1976).

8. Galas, D. J. \& Branscromb, E. W. Nature 262, 617-619 (1976).

9. Zengel, J. M., Young, R., Dennis, P. \& Nomura, M. J. Bact. 129, 1320-1329 (1977).

10. Fowler, A. V. \& Zabin, I. Proc. natn. Acad. Sci. U.S.A. 74, 1507-1510 (1977).

11. Kennell, D. \& Riezman, H. J. molec. Biol. 114, 1-21 (1977). 